\title{
Taking a Knee: An Analysis of the NFL's Decision to Relinquish Its § 501(c)(6) Federal Tax Exemption
}

\section{Dylan P. Williams}

\begin{abstract}
After 50 years as a nonprofit entity, the National Football League (NFL) voluntarily relinquished its favorable tax exemption. The NFL was exempt from paying federal income taxes due to its classification as a nonprofit organization according to Internal Revenue Code (IRC) Section (\$) 501(c)(6). This rule provides a tax exemption to organizations performing operations that further the industry or profession they represent. While professional football leagues are explicitly stated in $\$ 501(\mathrm{c})(6)$, the NFL's exemption only applied to its League Office opposed to the NFL Ventures partnership, which manages the league's business activities. As such, the NFL may have erred on deciding to forfeit their exemption. The purpose of this study is to review $\$ 501(c)(6)$ to determine if the League Office should maintain its exemption. The analysis shows the League Office cannot be considered an industry association due to the performance of particular activities for the benefit of its individual members.
\end{abstract}

In 2015, the National Football League renounced its controversial tax-exempt status and opted to classify as a taxable entity beginning in its 2015 fiscal year (Clegg, 2015). Originally, the NFL was considered a nonprofit entity due to an exemption granted to the league through Internal Revenue Code (IRC) §501(c)(6) (Griffin \& Kennedy, 2014; Schmied, 2014). This tax exemption is given to organizations performing operations that further the industry or profession they belong [Internal Revenue Service (IRS), 2006a]. Further, §501(c)(6) differs significantly from the more common $\$ 501$ (c)(3) exemption, which provides nonprofit status to charitable organizations for facilitating activities that provide the greater good to society (Williams \& Seifried, 2013). According to Spector (2013), the IRS considered the NFL to be a nonprofit organization since 1942. However, the league was granted an official exemption in 1966 after lobbying Congress for antitrust protection during its merger with the American Football League (AFL) (Dosh, 2013).

According to Houston Texans owner and Chairman of the NFL Finance Committee Robert McNair, the owners of the 32 NFL franchises decided "to eliminate the distraction associated with misunderstanding of the league office's status" (Belson, 2015, para. 5). Much of this distraction is derived from lawmakers who

Williams is with the Dept. of Kinesiology, The University of Alabama. Williams can be reached at dpwilliams@ua.edu. 
have criticized the league for not paying its fair share in taxes (Clegg, 2015). As an example, former Oklahoma Senator Tom Coburn frequently cited the NFL in his annual "Wastebook" where Coburn scrutinized several private entities and federal programs for wasteful projects costing U.S. taxpayers billions of dollars (Ehley, 2014). Coburn regularly argued the tax exemption for professional sports leagues cost taxpayers approximately $\$ 91$ million annually although this estimated figure is questionable (Roberts, 2015).

While the move to relinquish its tax-exempt status has earned the NFL goodwill among the general public (Gregory, 2015), there still are many misperceptions centering on the NFL's exemption. Specifically, the NFL's exemption only applied to its League Office, which manages the operations and transactions of its 32 franchises (Deloitte \& Touche, 2010a). The league's business activities are managed by NFL Ventures (NFLV), a partnership between the league and its teams (Deloitte \& Touche, 2010b). Because of this distinct separation, the NFL could have erred on deciding to forfeit its tax exemption. Thus, the purpose of this study is to determine if the NFL League Office should have maintained its tax-exempt status. This analysis reviews the requirements for $\$ 501(\mathrm{c})(6)$ status to determine if the League Office met these requirements. Specifically, this study determines if the League Office was justly classified as an industry association, meaning the league promotes the sport of professional football opposed to its own individual interests (Schmied, 2014). Finally, the present work discusses the future tax implications for the League Office and NFL as a whole.

\section{The §501(c)(6) Exemption}

IRC $\$ 501$ provides federal tax exemptions to 29 different types of nonprofit organizations (IRS, 2006a; Schmied, 2014). Maul (2011) explained these organizations can be divided among two categories: (a) organizations providing a public benefit; and (b) organizations that provide a mutual benefit. According to Williams and Seifried (2013), public benefit organizations are commonly known as §501(c)(3) organizations because these firms are founded through charitable, religious, scientific, or educational efforts. As such, $\$ 501(\mathrm{c})(3)$ provides these firms a favorable tax treatment because they foster activities serving the greater good to society (Craig \& Weisman, 1994; Smith, 2010).

However, the IRS also provides exemptions to other organizations. As an example, §501(c)(4) provides a tax-exemption to nonprofit civic organizations such as volunteer fire departments (IRS, 2006a). Similarly, §501(c)(6) provides an exemption to organizations performing operations to further the industry or profession they represent (IRS, 2006a). Scholars trace the conceptual origins of $\S 501(\mathrm{c})(6)$ to the Tariff Act of 1913 and the U.S. Chamber of Commerce's request for tax-exempt status for nonprofit civic and commercial organizations (Maul, 2011; Reilly, Hull, \& Allen, 2003). During this time, the Senate Finance Committee was encouraged to add an exemption covering nonprofit business groups (National Muffler Dealers Assn. [NMDA] v. United States, 1979). Along with the American Warehousemen's Association, a trade association for warehouse operators, the U.S. Chamber of Commerce argued its organization provided opportunities to build up trade and commerce within communities as a whole despite their goal of commercial advancement (Briefs \& Statements, 1913). Congress was receptive of 
the Chamber's rationale but rejected the Chamber's broad language, which would have exempted all commercial organizations for profit (NMDA v. United States, 1979). Instead, Congress altered the language of the Chamber's proposal, stating federal income tax would not apply to the following:

Business leagues, nor to chambers of commerce or boards of trade, not organized for profit or no part of the net income of which injures to the benefit of the private stockholder or individual. (Tariff Act of 1913, 1915, p. 172)

Section 501(c)(6) has stayed relatively the same with a few minor revisions over the last century. However, the phrase "business leagues" has been cumbersome for both the IRS and the courts as there was no common definition of the phrase. In 1919, the IRS attempted to define a business league as the following:

An association of persons with some common business interest, which limits its activities to work for such common interest and does not engage in a regular business of a kind ordinarily carried on for profit. Its work need not be similar to that of a chamber of commerce or board of trade. (Treasury Regulation 45, Art. 518, 1919)

Unfortunately, this language was then altered again since it proved hard to identify with precision the class of organizations Congress intended to exempt (NMDA v. United States, 1979). In 1924, the IRS denied an exemption requested by a stock exchange through noscitur a sociis, which defines words and phrases based on the words surrounding the ones in question (Treasury Regulation 69, Art. 518, 1926). For stock exchanges, the IRS believed that while an exchange could come within the definition of a business league, it does not contain the characteristics business leagues, chambers of commerce, or boards of trade share in common and form the basis for the exemption (NMDA v. United States, 1979).

In 1927, the Board of Tax Appeals applied noscitur a sociis and denied the exemption to a corporation organized by associations of insurance companies to provide printing services for member companies (Uniform Printing \& Supply Co. v. Commissioner, 1929). One year later, Congress amended §501(c)(6) through the Revenue Act of 1928 to include real estate boards in its listing (Reilly et al., 2003). Following this law, the IRS altered the language of the section while also incorporating noscitur a sociis within its framework to define business league in 1929. Specifically, the sentence, "Its work need not be similar to that of a chamber of commerce or board of trade," was replaced with the following:

It is an organization of the same general class as a chamber of commerce or board of trade. Thus, its activities should be directed to the improvement of business conditions or to the promotion of the general objects of one or more lines of business as distinguished from the performance of particular services for individual persons. (Treasury Regulation 74, Art. 528, 1929)

Although some language would be removed (i.e., "or to the promotion of the general objects”), §501(c)(6) has largely been unchanged until 1966. In, 1966, Public Law 89-800 amended \$501(c)(6) to include professional football leagues as tax-exempt organizations (Schmied, 2014). Since then, §501(c)(6) has not received any further alterations or amendments. 


\section{How the NFL Gained §501(c)(6) Status}

The inclusion of the phrase "professional football leagues" in §501(c)(6) is traced back to the NFL-AFL merger in 1966 (Dosh, 2013). The AFL and NFL competed with each other throughout the 1960s for fans, players, coaches, and television coverage (Crepeau, 2014). The battle intensified after the Sports Broadcasting Act of 1961 was passed, which allowed professional sports leagues to negotiate television-broadcast agreements normally considered price collusion and in violation of federal antitrust laws (Easterbrook, 2013). Both leagues quickly negotiated pooled television deals upon the passage of the Act, generating higher revenues in the process (Quirk \& Fort, 1997; Seifried \& Pastore, 2009).

As time progressed, several NFL owners were concerned about the rising expenses for talent, including an estimated \$25 million in signing bonuses in 1966 (MacCambridge, 2005). This concern led Dallas Cowboys President Tex Schramm to discuss plans for an AFL-NFL merger with NFL Commissioner Pete Rozelle (Crepeau, 2014). Rozelle appointed Schramm to represent the NFL in discussions with the AFL and Kansas City Chiefs owner Lamar Hunt (Schramm, 1966). The two groups agreed to merge but needed Congress to provide the merger an exemption to antitrust laws since the two leagues would have a monopoly regarding professional football television rights (Easterbrook, 2013).

According to MacCambridge (2005), getting Congressional approval for the merger required some extensive political positioning. Despite initial positive reaction from the Senate Anti-Monopoly subcommittee, Congressman Emmanuel Celler and the House Judiciary Committee opposed the merger (Crepeau, 2014). To circumvent Celler, Rozelle met with House Majority Whip Hale Boggs and Senate Majority Whip Russell Long of Louisiana, two powerful men in Congress during the 1960s (Barbash, 2014). Rozelle met with both Boggs and Long through David Dixon, a New Orleans entrepreneur who desired to bring an NFL franchise to the city (Sandomir, 2010). Both Boggs and Long were receptive of Rozelle's idea as long as New Orleans was guaranteed an NFL franchise (Barbash, 2014). Furthermore, Boggs believed acquiring a franchise for New Orleans would help his popularity in Louisiana after supporting the 1965 Voting Rights Act (Crepeau, 2014; MacCambridge, 2005).

To circumvent Cellar and the House Judiciary Committee, an amendment was attached to Public Law 89-800, a vital budget bill certain to pass both houses (Crepeau, 2014; Schmied, 2014). Specifically, this proposed bill was crafted to suspend the investment credit and the allowance of accelerated depreciation in the case of certain real property (Public Law 89-800, 1966). Furthermore, Congress decided to keep Public Law 89-800 very low profile due to two major factors involving the treatment of the NFL and other professional leagues under federal law (Easterbrook, 2013). First, it broadened the antitrust exemptions established in the Sports Broadcasting Act, allowing the AFL and NFL to merge without issue (Schmied, 2014). Second, NFL lobbyists negotiated for lawmakers to add the phrase "professional football leagues (whether or not administering a pension fund for football players)" in $§ 501(\mathrm{c})(6)$, saving the league millions in tax obligations (Easterbrook, 2013). According to Zhang (2013), this extra provision was added for the NFL since the inclusion of a pension plan would be considered as benefitting a private individual. After an extensive political process, the NFL, or more specifically 
professional football leagues, obtained its $\$ 501(\mathrm{c})(6)$ tax exemption on November 8, 1966 when Public Law 89-800 (1966) was signed into law.

\section{Application of $\S 501(c)(6)$}

While $\$ 501(c)(6)$ explicitly lists professional football leagues, any professional sports league can theoretically claim $\$ 501(\mathrm{c})(6)$ status if it meets the law's requirements (Maul, 2011). As of 2015, the National Hockey League (NHL), the Professional Golf Association (PGA), and the National Hot Rod Association (NHRA) are all classified as $\$ 501(c)(6)$ organizations (Ferguson, 2012). Major League Baseball (MLB) originally filed as a $\$ 501(\mathrm{c})(6)$ entity but chose to forego its tax-exempt status to avoid making disclosures about the compensation of its top executives on its annual tax return (Maul, 2011).

According to Bittker (1999) and Maul (2011), §501(c)(6) organizations fall under the mutual benefit category of tax-exempt organizations since they are created and developed for the mutual benefit of their members as opposed to the public at large. Organizations desiring to qualify for $\$ 501(\mathrm{c})(6)$ status must meet the requirements of the statute itself as well as Treasury Regulation 1.501(c)(6)-1 (1978). As such, a $\$ 501(c)(6)$ firm must be an association:

(1) of persons having a common business interest; (2) the purpose of which is to promote such common business interest; (3) and not to engage in a regular business of a kind ordinarily conducted for profit . . ; (4) an organization of the same general class as a chamber of commerce or board of trade . .; (5) its activities should be directed to the improvement of business conditions of one or more lines of a business as distinguished from the performance of particular services for individual persons. (Treas. Reg. 1.501(c)(6)-1, 1978, para. 1)

In addition, a $\$ 501(\mathrm{c})(6)$ organization's net earnings cannot benefit any private individual nor can the firm be organized for-profit (IRS, 2006a). Furthermore, $\$ 501(\mathrm{c})(6)$ entities can engage in political campaigns or lobbying efforts, provided the activity is related to the organization's exempt purpose (Reilly \& Allen, 2003). For example, the U.S. Chamber of Commerce regularly engages in lobbying practices to encourage the development of business both domestically and internationally (Steinbach, 2013). Finally, contributions to a $\$ 501(\mathrm{c})(6)$ in the form of dues or activity support cannot are not considered a charitable deduction (IRS, 2006a).

Although the exemption does not require these organizations to pay federal income taxes, the IRS can impose taxes on $\$ 501(\mathrm{c})(6)$ organizations on income that is unrelated to their primary business activities. In 1950, Congress instituted the unrelated business income tax (UBIT), which taxes nonprofit organizations on activities that are regularly performed but are drastically different from their exempt purpose (Williams \& Seifried, 2013). As an example, the mission for a university or college is to provide educational benefits to all enrolled students, which allows schools to qualify as a $\$ 501(c)(3)$ organization (Kaplan, 1980). Should the school begin operations of activities that are not connected to the educational benefit of the institution, the IRS is allowed to impose taxes on the school for the unrelated business income (Williams \& Seifried, 2013). However, UBIT can be charged to all $\S 501$ exempt organizations, including those qualified as a $\$ 501(\mathrm{c})(6)$ organization (Arnsberger, Ludlum, Riley, \& Stanton, 2008). 


\section{NFL Business League Structure}

To properly assess the importance of its tax-exempt status, one must explore the league's structure and organization. Originally organized in 1920, the NFL is defined as a joint venture comprised of the 32 independently owned and operated franchises (He, 2014). All 32 franchises pay annual non tax-deductible assessments to the League Office to cover overhead activities such as office rent, executive salaries, and game officiating (Dosh, 2013). These assessments are the League Office's major source of revenue while the largest operating expenses are general and administrative activities (Deloitte \& Touche, 2010a). According to the 2013-14 NFL tax return, the league office collected approximately \$294 million in membership dues and assessments (Department of the Treasury, 2013). In addition, the League Office also manages the G-3 Stadium Program, which provides franchises financial support through interest-free loans for stadium construction and/or renovation projects (Deloitte \& Touche, 2010a). However, in 2011, the League Office created a new stadium financial support program, the G-4 Stadium Program, but relinquished all management responsibilities to NFLV to avoid issues of losing their exempt status (van den Berg, 2013). According to its 2013 tax return, the League Office reported a net loss of approximately $\$ 13$ million, one year after reporting net income of approximately $\$ 9$ million (Department of the Treasury, 2012).

While the League Office can show a net loss, the league is comprised of several entities that can mitigate the League Office's losses. Originally, the individual franchises acted independently in regards to licensing and marketing their intellectual property in its early history (American Needle v. NFL, 2010). In 1963, however, the teams opted to forfeit their individual trademark rights and pooled their intellectual property under an agreement which formed NFL Properties (NFLP) (He, 2014). Under this collective agreement, NFLP is responsible for the licensing and marketing of trademarks and logos of each team (American Needle v. NFL, 2010).

Similarly, in 1994, NFLV was created in order "to advertise, promote and market the NFL and its Member Clubs" (Deloitte \& Touche, 2010b, p. 6). This partnership operates several wholly-owned subsidiaries that are in charge of NFL's various activities including NFLP, NFL Enterprises, NFL Productions, and NFL International (Deloitte \& Touche, 2010b). NFLV manages its own set of consolidated financial statements, presenting the financial position of NFLV and its subsidiaries as a single economic entity (Ernst \& Young, 2014). As such, revenue generated from television contracts, sponsorships, licensing, advertising, digital media, and film rights are consolidated into one set of financial statements (Deloitte \& Touche, 2010b).

Furthermore, each NFL franchise receives a share of the corporate sponsorship and license revenue generated by NFLV (Deloitte \& Touche, 2010b). This revenue is pass-through revenue since it transfers from the partnership to each team (Ernst \& Young, 2014). Similarly, each franchise receives a film royalty and an annual license fee, which is calculated as the total gross revenue of NFLV and its profitable subsidiaries less 1.09 times the sum of the partnership's expenses (Deloitte \& Touche, 2010b). The 2010 financial statements show NFLV distributed over $\$ 1.25$ billion in license fees and $\$ 6$ million in royalty expenses to each individual franchise, showing \$42 million in net income (Deloitte \& Touche, 2010b).

Similar to the League Office, NFLV is not subject to federal, state, or local income taxes (Deloitte \& Touche, 2010b). However, NFLV is organized as a for-profit entity, 
which disqualifies it from the $\$ 501(\mathrm{c})(6)$ tax exemption. Instead, NFLV is exempt from taxes due to its organizational structure as a partnership among the 32 member clubs. According to Larson (2010), partnerships are defined as flow-through entities. As such, any taxable items earned by the partnership flow through to each partner, according to the partnership agreement, and are reported on each partner's respective individual tax returns (Larson, 2010). In terms of NFLV, all 32 franchises, specifically their owners, are the partners for this business venture and must report their share of the entity's net income or loss on their annual tax returns (Deloitte \& Touche, 2010b). Despite this classification, NFLV is required to pay both New York City unincorporated business taxes and certain foreign income taxes as well as federal, state, and local taxes for activities of NFL Productions and NFL International (Deloitte \& Touche, 2010b).

\section{Criticism of the NFL's Exemption}

Although the NFL's $\$ 501(c)(6)$ exemption applied to the League Office, several U.S. lawmakers proposed legislation to remove the exemption due to the league's business activities (Chemi, 2014). Senator Coburn submitted several bills to strip the NFL of its exemption including the PRO Sports Act, which prohibited professional sports organizations with annual revenue over $\$ 10$ million from filing as a nonprofit entity (Boudway, 2013). He estimated the U.S. Treasury would save over $\$ 100$ million during the next 10 years if Congress revoked the exemption (Manohar, 2013). Similarly, Senator Cory Booker of New Jersey proposed the Securing Assistance for Victim Empowerment (SAVE) Act following the Ray Rice and Adrian Peterson domestic abuse scandals in 2014, which would collect taxes from the NFL for domestic abuse programs across the country (Tracy, 2014; Weissmann, 2014). Finally, Senator Maria Cantwell of Washington drafted a similar bill after issues over the Redskins team name surfaced (Katzowitz, 2014). However, none of these bills gained widespread support in Congress.

In addition to legislators, many ordinary U.S. citizens have been outraged with how the NFL managed certain events such as the punishment of players for offfield behaviors (Heitner, 2014), the health of current and former players regarding concussions (Almasy \& Martin, 2015), and access to games on television (Patra, 2015). As such, political activist Lynda Woolard decided to take action by creating an online petition, asking Congress to revoke the League Office's tax-exempt status (Schmied, 2014). The petition received over 400,000 individual signatures, causing Congress to explore the situation and ultimately the NFL to forfeit their nonprofit status (Woolard, 2013). With pressure from both citizens and lawmakers, as well as the NFL's questionable management of the polarizing issues mentioned earlier, the NFL chose to forfeit its exempt status and end "the distraction" (Rovell, 2015, para. 3). Although applauded by the general public for forfeiting its exemption (Gregory, 2015), one can determine if the League Office erred in its decision to voluntary relinquish its $§ 501(c)(6)$ status.

\section{Reexamining the NFL's §501(c)(6) Status}

As noted earlier, for an entity to qualify as an $\$ 501(\mathrm{c})(6)$ organization, it must meet five requirements as stated in Treasury Regulation 1.501(c)(6)-1 (1978). This analysis explores each component to review if the NFL League Office meets the IRC's definition of a $\$ 501(\mathrm{c})(6)$ entity. 


\section{Component \#1: Common Business Interest}

For an entity to qualify for $\$ 501(\mathrm{c})(6)$ status, it must first establish a common business interest among members of the organization (Reilly et al., 2003). According to Associated Industries of Cleveland v. Commissioner of Internal Revenue (1946), business is constructed broadly and can embrace everything about which a person can be employed. Furthermore, the IRS interprets "person" as any individual or legal entity (i.e., corporation or trust) (Schmied, 2014). According to its 2010 financial statements, the League Office "was established by the [32] Member Clubs of the National Football League . . . to administer the joint operations of the league and the Member Clubs, including transactions common to all the Member Clubs" (Deloitte \& Touche, 2010a, p. 7). Thus, all 32 franchises can be defined as "people", working together to develop and manage professional football. As such, the League Office satisfies this component.

\section{Component \#2: Promotion of Common Business Interest}

The League Office and its franchises work on the promotion and advancement of professional football. Thus, the League Office successfully satisfies the second requirement. However, it is important to note this common interest may be narrower than appears, which could have implications for other components (Cohen, 2013; Hruby, 2013).

\section{Component \#3: For Profit Organization and Operation}

Much criticism for the NFL's tax exemption centers on the league's profitability and the exorbitant salaries of NFL officials (Dosh, 2013; Lo, 2014). Table 1 provides the reported salaries for top ranking NFL officials during the 2011, 2012, and 2013 fiscal years. For an organization to be considered not-for-profit, an entity does not have to operate at a loss or have expenses continually exceed revenue (Schmied, 2014). Instead, Reilly et al. (2003) note the crucial inquiry relates to the distribution of income to the association's members. Furthermore, a $\$ 501$ (c) (6) firm cannot engage in any trade or business ordinarily conducted for profit. According to $\$ 513$ (c), a trade or business can be any activity carried out to produce income (IRS, 2006b). The IRS analyzes the nature of the activity to determine if a business is ordinarily carried on for profit (Reilly et al., 2003). Specifically, the courts argue an association that creates and sells a product while investing in the protection through trademark infringement of the product is engaged in business ordinarily conducted for profit (Bluetooth SIG Inc. v. United States, 2010). However, the courts provide an exception for associations participating in activities ordinarily conducted for profit if engagement is an incidental activity to the association's purpose (Schmied, 2014). According to Plunkett and Christianson (2004), any activity lasting a short period of time, such as a fundraiser, is not considered a regularly carried on business. However, Treasury Regulation 1.513-1(c)(2)(i) (1983) notes seasonal activities can be considered regularly carried out if they occur during a significant portion of the year.

When studied as a whole, the NFL cannot classify as a nonprofit entity due to its billions in revenue (Maul, 2011). When analyzed separately, however, the League Office only manages the interests of the league and its franchises including 


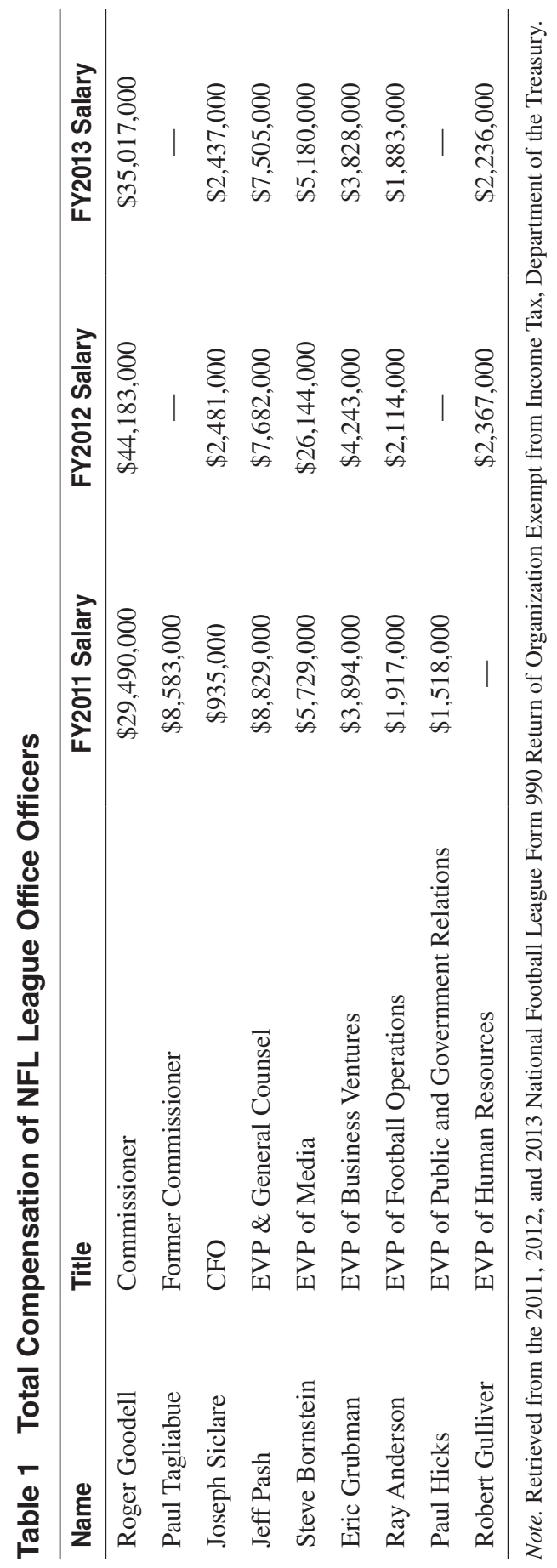


its revenue sharing mechanism, where it collects and distributes revenues on behalf of the 32 franchises (Dosh, 2013). Although collected from national revenue (Rovell, 2014), the League Office acts only as a distributor while NFLV is in charge of this source. Further, the League Office's main responsibilities include establishing rules, developing effective programs to run operations, and promoting business in the broader community (Spector, 2013). As such, the League appears to be organized as a nonprofit entity.

\section{Component \#4: Similar Board of Trade}

The courts state for an association to classify as a board of trade, it must possess the general characteristics of a board of trade (Produce Exchange Stock Clearing v. Helvering, 1934). Schmied (2014) notes the important factors for the courts are the purposes and operations of the board of trade and how they relate to the applying association. Specifically, the courts will determine if the association promotes a common business interest (Component \#1), is similar to other boards of trade, and does not engage in activities ordinarily carried on for profit (Component \#3) (Retailers Credit v. Commissioner, 1937). To distinguish boards of trade from chambers of commerce, Retailers Credit v. Commissioner (1937) defined trade associations as a body of individuals focused on the advancement and protection of business interests. Chambers of commerce are defined similarly but focuses on all commercial interests in a particular geographic area opposed to the promotion of a specific line of business (Schmied, 2014). According to its 2012 tax return, the League Office's mission states it is a "trade association promoting interests of its 32 member clubs" (Department of the Treasury, 2012, p. 1). As such, it cannot be considered as a chamber of commerce. Instead, the League Office focuses on the promotion and advancement of professional football in the U.S. as well as internationally (Deloitte $\&$ Touche, 2010a). Thus, the League Office satisfies this component.

\section{Component \#5: Improvement of Business Conditions}

For associations to satisfy this component, it must pass two analyses: (a) a line of business analysis and (b) a performance of particular services analysis (Schmied, 2014).

\section{Line of Business}

While the language of $\S 501(\mathrm{c})(6)$ has not changed for nearly half a century, both the IRS and the courts have been charged with defining the phrase "line of business." Several prominent court cases interpret the phrase to fall into one of two different categories: (1) an entire industry (American Plywood Assn. v. United States, 1967; National Leather \& Shoe Finders Assn. [NLSFA] v. Commissioner, 1947) or (2) all components of an industry within a particular geographic area (Commissioner v. Chicago Graphic Arts Federation, Inc., 1942). However, the courts did provide one organization with $\S 501(\mathrm{c})(6)$ status that did not fall within either category.

In 1966, the Pepsi-Cola Bottlers' Association (PCBA) was a trade association organized to promote, protect, extend, and improve the business of bottling and selling Pepsi-Cola (Pepsi-Cola Bottlers'Association [PCBA] v. United States, 1966). When PCBA filed for $\$ 501(c)(6)$ status, the organization was denied. The 
IRS argued PCBA was denied because the IRS has never given the exemption to organizations associated with one particular brand of product. Nonetheless, the courts argued PCBA falls within the scope of $\$ 501(\mathrm{c})(6)$, noting a business league need not be devoted to the general public welfare entirely ( $P C B A$ v. United States, 1966). However, the IRS disagrees with this ruling and argues groups representing a particular product do not have the best interests of an entire industry (NMDA v. United States, 1979). As such, the IRS defines a line of business as a trade or occupation that does not restrict entry through patents, trademark, or other means that restrict business engagement (Treas. Reg. $\S 1.501(\mathrm{c})(6)-1,1978)$.

For the League Office to pass this analysis, one must first establish the industry the NFL and its franchises promote. The Supreme Court originally provided insight on the how to define the NFL in the case NMDA v. United States (1979). Specifically, the Supreme Court stated the NFL represented the industry of professional football while the NMDA represented a small percentage of franchises that sold a particular brand of mufflers. While NMDA v. United States (1979) acknowledged and upheld the IRS two category definition of "line of business," Schmied (2014) argues the court's analysis of the NFL is outdated since other professional football leagues have existed before (e.g., Canadian Football League [CFL]) and after the case's ruling (e.g., Arena Football League [ArFL]). He further argues if the NFL was representative of an entire industry, then it should incorporate these teams from these leagues into its ranks. While there is no evidence to suggest future mergers (Dosh, 2013), the NFL maintains working relationships with other leagues. As an example, the ArFL signed a broadcast deal in 2010 with the NFL to have weekly games broadcasted on the NFL Network (Lombardo \& Ourand, 2010). Similarly, the CFL scheduled preseason games with NFL franchises during the 1950s (Florio, 2012). Finally, many players and coaches from other professional football leagues have earned similar positions in the NFL. Because of these working relationships, the League Office seems to advance and promote the professional football industry, passing the Line of Business analysis.

\section{Performance of Particular Services}

The IRS will not grant $\$ 501(c)(6)$ status if an organization has its primary activity perform particular services directed at individual persons (Reilly et al., 2003). For example, if a shopping center's advertisements contained the names of individual merchants, the merchants of the shopping center would be denied §501(c)(6) status. However, if a general advertising campaign was created that encouraged an entire industry's products and services, the IRS would not have issue (Reilly et al., 2003). Furthermore, the courts argue if a firm benefits only those associated with the organization, $\$ 501(\mathrm{c})(6)$ status will denied (Schmied, 2014). Finally, one of the major factors in determining the performance of particular services is whether the particular service is supported by the organization's fees and assessments in proportion to the benefits received by the member firms (MIB, Inc. v. Commissioner, 1983). For example, MIB, Inc. is a clearinghouse for life insurance companies, helping its members determine if applicants are hiding medical limitations. Most of the dues and assessments collected by MIB were related directly to the information exchange MIB established. While the dues were based on member size and sales volume, the courts argued nearly half of the assessments received by MIB were 
the result of a direct exchange for information based upon the number of requests processed (MIB, Inc. v. Commissioner, 1983). Due to this rationale, the courts denied MIB $§ 501(\mathrm{c})(6)$ status.

However, the definitive decision regarding performance of particular services centers on if an association's activities advance the interests of its members through membership in a particular industry or whether the association assists members in the pursuit of each individual member's business (NLSFA v. Commissioner, 1947). As stated earlier, the assessments collected from the 32 franchises are used for overhead activities (Deloitte \& Touche, 2010a). According to Dosh (2013), the League Office would argue it does not perform any particular services for its member teams. However, as Schmied (2014) identifies, the relationship between the League Office and NFLV could be of concern. Specifically, one could reasonably argue the NFL performs particular services for its members based on the activity performed by NFLV and its subsidiaries for the benefit of the league's franchises. For example, NFL Productions "primarily produces NFL-related programming for the NFL and its Member Clubs" while NFL Enterprises "consist primarily of advertising, publicizing, promoting, marketing and selling broadcasts of NFL games through 'NFL Sunday Ticket' and related programming, including NFL Network" (Deloitte \& Touche, 2010b, p. 6).

Based on the relationship between the League Office, NFLV, and its subsidiaries, it appears the League Office's primary activity involves the performance of particular services for the benefit of the NFL and its franchise owners. Furthermore, the G-3 and G-4 Stadium Programs also raise questions regarding particular service performance. Under this system, the league negotiates stadium deals comprised of public money, NFL loans, and ownership financing (Delaney, 2010; van den Berg, 2013). When the League Office provides financial support to teams seeking stadium construction or renovation, these teams' owners receive a significant benefit at the expense of other owners (deMause, 2011). While the NFL would argue the program is a promotional activity and only produces incidental benefits, the unequal fund distribution violates the performance of particular activities as well as private inurement (Schmied, 2014). Thus, the League Office would fail this component overall.

\section{Future Implications}

Organizations possessing a tax exemption through $§ 501$ (c) generally do so because they provide activities that serve the greater good to society (Smith, 2010). As an example, charitable nonprofit firms (e.g., churches, schools, etc.) obtain an exemption through $\$ 501(\mathrm{c})(3)$ because they advance a charitable purpose (e.g., religion, education, etc.) (Williams \& Seifried, 2013). Similarly, associations dedicated to assisting small businesses advance their industry or improve within their geographic region are provided a tax exemption due to $\$ 501(\mathrm{c})(6)$. Like $\$ 501(\mathrm{c})(3)$ firms, $\$ 501(\mathrm{c})(6)$ are not organized for profit and no part of the net earnings from the association should benefit any private shareholder or individual (Reilly et al., 2003).

In order for the NFL League Office to qualify for $\$ 501(\mathrm{c})(6)$ status, it must meet the five requirements outlined in Treasury Regulation 1.501(c)(6)-1 (1978). Despite the enclosure of "professional football leagues" in the code, the League Office does not appear to meet all the requirements for $\$ 501(c)(6)$ status. Specifically, the 
League Office's partnership with NFLV and its G-3 and G-4 Stadium Programs call into question whether the activities performed by the organization are designed to benefit the respective owners of the 32 NFL franchises or the industry of professional football. While the league partnered with other professional football leagues in the past (Florio, 2012; Lombardo \& Ourand, 2010), these events appear to be incidental in nature and not a primary activity of the league. Based on this analysis, the League Office was correct to forfeit its tax-exempt status.

In doing so, the League Office structure will change from a trade association to a corporation, similar to MLB (Maul, 2011). From a financial perspective, however, this change will not generate a tremendous impact. As an example, the League Office reported approximately \$9 million in net income on its 2012-13 tax return (Department of the Treasury, 2012). Using the corporate tax tables provided by the IRS, the League Office would have to pay approximately $\$ 3.05$ million in federal income taxes. While this appears to be a substantial amount, one must note the League Office generates nearly $\$ 300$ million in revenue annually through its Member Club assessments (Department of the Treasury, 2012, 2013). Furthermore, if the League Office chose to classify as a corporation, specifically a C-Corporation, then it can use a tax deduction based upon its net operating losses (NOL). According to its tax returns, the League Office reported net losses of \$52 million, \$78 million, and \$13 million in the 2010, 2011, and 2013 fiscal years respectively (Department of the Treasury, 2011, 2012, 2013). If the entity operated as a C-Corporation in those years, the League Office would not have to pay income taxes due to the NOL. Further, the League Office could carry the NOL to use in the prior two years as a tax deduction or potentially carry the NOL forward over the next 20 years (IRS, 2014). As such, any potential taxable income could be offset by prior or future NOL, reducing the collection of federal income taxes from the League Office to zero.

While the change in tax status does not appear to have an economic impact, the forfeiture of the $\$ 501(\mathrm{c})(6)$ exemption allows the NFL to file a much easier return since a corporate tax return does not require disclosures on the inner workings of the company. Specifically, corporations file a Form 1120 and report on the income, gains, losses, deductions, credits, and calculation of an entity's income tax liability (IRS, 2015). In comparison, Form 990 requires nonprofit entities to report on their organization's activities (exempt and nonexempt), finances, governance, compliance with federal tax filings and requirements, and compensation paid to certain persons since the organization is considered a public entity (IRS, 2014). Thus, the biggest changes to the change in tax structure benefits the League Office from a reporting standpoint. The most important item the League Office does not have to disclose is the compensation of the top ranking officers and highest compensated employees (IRS, 2015). As such, the general public will no longer have access to the exorbitant salaries of Commissioner Goodell and other officers of the League Office (Dosh, 2013; Lo, 2014).

Based on these results, it appears the League Office's change in tax-exempt status does not have the economic effect lawmakers assumed it would (Roberts, 2015). However, the pressure from the general public and lawmakers should not be in vain as both parties did force the NFL to correct a legislative error regarding §501(c)(6). Instead, this change in tax-exempt status will put pressure on other professional leagues like the NHL and PGA Tour to reevaluate their $\$ 501(c)(6)$ status. While one can assume 
either league is simply promoting the interests of its membership, future research should explore whether these organizations meet Treasury Regulation 1.501(c)(6)-1 (1978) requirements. Finally, Congress should continue to explore potential litigation to remove the phrase "professional football leagues" from \$501(c)(6) and prohibit professional sports leagues from obtaining tax-exempt status in the future.

\section{References}

Almasy, S., \& Martin, J. (2015, April 22). Judge approves NFL concussion lawsuit settlement. Retrieved from http://www.cnn.com/2015/04/22/us/nfl-concussion-lawsuit-settlement/. American Needle, Inc. v. National Football League et al., 130 S.Ct. 2201 (2010).

American Plywood Assn. v. United States, 267 F. Supp. 830 (WD Wash. 1967).

Arnsberger, P., Ludlum, M., Riley, M., \& Stanton, M. (2008). A history of the tax-exempt sector: An SOI perspective. Statistics of Income Bulletin, 27, 105-135.

Associated Industries of Cleveland v. Commissioner of Internal Revenue, 7 T.C. 1449 (1946).

Barbash, F. (2014, September 15). Why Congress will never take back the NFL's tax break. The Washington Post. Retrieved from http://www.washingtonpost.com/news/morning$\mathrm{mix} / \mathrm{wp} / 2014 / 09 / 15 /$ why-congress-will-never-take-back-the-nfls-huge-tax-break/.

Belson, K. (2015, April 28). After much criticism, N.F.L.'s league office drops tax-exempt status. The New York Times. Retrieved from http://www.nytimes.com/2015/04/29/sports/ football/nfls-league-office-to-drop-its-tax-exempt-status.html.

Bittker, B.I. (1999). Federal taxation of income, estates and gifts. Valhalla, N.Y. Warren: Gorham, \& Lamont.

Bluetooth SIG Inc. v. United States, 611 F.3d 617 (9th Cir. 2010).

Boudway, I. (2013, September 19). A Republican Senator's lonely mission to make the NFL pay taxes. Retrieved from http://www.businessweek.com/articles/ 2013-09-19/a-republican-senator-s-lonely-mission-to-make-the-nfl-pay-taxes.

Briefs and Statements on H. R. 3321 filed with the Senate Committee on Finance, Senate, 63 ${ }^{\text {rd }}$ Cong. (1913).

Chemi, E. (2014, September 12). If the NFL were a real business. Retrieved from http:// www. businessweek.com/articles/2014-09-12/if-the-nfl-were-a-real-business.

Clegg, J. (2015, April 28). NFL to end tax-exempt status. The Wall Street Journal. Retrieved from http://www.wsj.com/articles/nfl-to-end-tax-exempt-status-1430241845.

Cohen, R. (2013, January 11). In Santa Clara, tax-exempt NFL looks like a for-profit business. Retrieved from https://nonprofitquarterly.org/policysocial-context/21662-in-santa-claratax-exempt-nfl-looks-like-a-business.html.

Commissioner v. Chicago Graphic Arts Federation, Inc., 128 F. 2 d 424 (CA7 1942).

Craig, C., \& Weisman, K. (1994). Collegiate athletics and the unrelated business income tax. Journal of Sport Management, 8, 36-48.

Crepeau, R.C. (2014). NFL football: A history of America's new national pastime. Chicago, IL: University of Illinois Press.

Delaney, A.B. (2010). Taking a sack: The NFL and its undeserved tax-exempt status. Social Science Research Network. Retrieved from http://papers.ssrn.com/sol3/papers.cfm? abstract_id=1605281.

Deloitte \& Touche. LLP. (2010a). National Football League league office: Independent auditors' report - Financial statements as of and for the years ended March 31, 2010 and 2009. Retrieved from http://edge-cache.deadspin.com/deadspin/nflleagueoffice.pdf.

Deloitte \& Touche. LLP. (2010b). NFL Ventures, L.P. and subsidiaries: Independent auditors' report - Consolidated financial statements and supplemental schedules as of and for the years ended March 31, 2010 and 2009. Retrieved from http://edge-cache.gawker. $\mathrm{com} /$ deadspin/nflventures.pdf. 
deMause, N. (2011, July 26). The NFL's new stadium fund explained (sort of). Retrieved from http://www.fieldofschemes.com/?s=The $\% 20$ NFL $\% 27 \mathrm{~s} \% 20$ new $\% 20$ stadium $\% 20$ fund $\% 2$ 0explained $\% 20 \% 28$ sort $\% 20$ of $\% 29 \&$ submit=Search.

Department of the Treasury. (2011). National Football League Tax Return (Form 990). Washington, D.C.: Internal Revenue Service Individual Forms and Publications Branch.

Department of the Treasury. (2012). National Football League Tax Return (Form 990). Washington, D.C.: Internal Revenue Service Individual Forms and Publications Branch.

Department of the Treasury. (2013). National Football League Tax Return (Form 990). Washington, D.C.: Internal Revenue Service Individual Forms and Publications Branch.

Dosh, K. (2013, June 4). Examining NFL's tax-exempt status. Retrieved from http://espn.go.com/ nfl/story/_id/9342479/examining-nfl-tax-exempt-status-challenged-us-senator-tom-coburn.

Easterbrook, G. (2013, September 18). How the NFL fleeces taxpayers. The Atlantic. Retrieved from http://www.theatlantic.com/magazine/archive/2013/10/how-the-nflfleeces-taxpayers $/ 309448 /$ ?single_page $=$ true.

Ehley, B. (2014, October 22). Coburn's 2014 Wastebook: A \$25 billion taxpayer loss. The Fiscal Times. Retrieved from http://www.thefiscaltimes.com/2014/10/22/Coburn-s2014-Wastebook-25-Billion-Taxpayer-Loss.

Ernst \& Young. LLP. (2014). Consolidated and other financial statements: Noncontrolling interests, combined financial statements, parent company financial statements, and consolidating financial statements. New York, NY: Author.

Ferguson, J. (2012, October 18). The NFL, NHL, PGA are all nonprofit, tax-exempt organizations. The Deseret News. Retrieved from http://www.deseretnews.com/article/ 865564748/ The-NFL-NHL-PGA-are-all-nonprofit-tax-exempt.organizations.html?pg= all.

Florio, M. (2012, June 23). NFL, CFL used to meet in the preseason. Retrieved from http:// profootballtalk.nbcsports.com/2012/06/23/nfl-cfl-teams-used-to-meet-in-thepreseason/.

Gregory, S. (2015, April 28). Why the NFL suddenly wants to pay taxes? Retrieved from http:// time.com/3839164/nfl-tax-exempt-status/.

Griffin, D., \& Kennedy, S. (2014, September 23). Is the NFL skirting the tax man? Retrieved from http://www.cnn.com/2014/09/22/us/nfl-nonprofit-taxes/.He, Y. (2014). American Needle upon remand. Seton Hall Journal of Sports and Entertainment Law, 24, 43-80.

He, Y. (2014). American Needle upon remand. Seton Hall Journal of Sports and Entertainment Law, 24, 43-80.

Heitner, D. (2014, September 23). Will NFL's tax-exempt status sustain attack by members of Congress? Retrieved from http://www.forbes.com/sites/darrenheitner/2014/ 09/23/ will-nfls-tax-exempt-status-sustain-attack-by-members-of-congress/.

Hruby, P. (2013, October 1). The people vs. NFL welfare. Sports on Earth. Retrieved from http://www.sportsonearth.com/article/62280950/.

Internal Revenue Service. (2006a). Internal Revenue Code (\$501). Washington, D.C.: Author. Retrieved from http://www.law.cornell.edu/uscode/text/26/501.

Internal Revenue Service. (2006b). Internal Revenue Code (\$513(c)). Washington, D.C.: Author. Retrieved from http://www.law.cornell.edu/uscode/text/26/513.

Internal Revenue Service. (2014). 2014 Instructions for Form 990. Washington, D.C.: Author.

Internal Revenue Service. (2015). 2014 Instructions for Form 1120. Washington, D.C.: Author.

Kaplan, R. (1980). Intercollegiate athletics and the unrelated business income tax. Columbia Law Review, 80, 1430-1473. doi:10.2307/1122171

Katzowitz, J. (2014, September 16). Sen. Maria Cantwell to introduce bill to end NFL's taxexempt status. Retrieved from http://www.cbssports.com/nfl/eye-on-football/24711974/ sen-maria-cantwell-to-introduce-bill-to-end-nfls-tax-exempt-status.

Larson, J. (2010). Partnership taxation: An application approach. Durham, NC: Carolina Academic Press. 
Lo, A. (2014, May 15). America's sport audited. Harvard Political Review. Retrieved from http://harvardpolitics.com/books-arts/americas-sport-audited/.

Lombardo, J., \& Ourand, J. (2010, February 8). NFL Network to broadcast new arena league's games. Sports Business Journal. Retrieved from http://www.sportsbusinessdaily.com/ Journal/Issues/2010/02/20100208/This-Weeks-News/NFL-Network-To-BroadcastNew-Arena-Leagues-Games.aspx.

MacCambridge, M. (2005). America's game: The epic story of how pro football captured a nation. New York, NY: Anchor Books.

Manohar, A. (2013, January 12). Take a hike! Why the NFL shouldn't enjoy tax-exempt status. The Jeffrey S. Moorad Center for the Study of Sports Law. Retrieved from http:// lawweb2009.law.villanova.edu/sportslaw/?p=1446.

Maul, J. (2011). America's favorite "nonprofits": Taxation of the National Football League and sports organizations. UMKC Law Review, 80, 199-220.

MIB, Inc. v. Commissioner of Internal Revenue, 80 T.C. 438 (1983).

National Leather \& Shoe Finders Assn. v. Commissioner, 9 T.C. 121 (1947).

National Muffler Dealers Association, Inc. v. United States, 440 U.S. 472 (1979).

Patra, K. (2015, March 23). NFL suspends local blackout policy for 2015. Retrieved from http://www.nfl.com/news/story/0ap3000000480822/article/nfl-suspends-local-blackoutpolicy-for-2015.

Pepsi-Cola Bottlers' Association, Inc. v. United States, 369 F.2d 250 (1966).

Plunkett, J., \& Christianson, H. (2004). The quest for cash: Exempt organizations, joint ventures, taxable subsidiaries, and unrelated business income. William Mitchell Law Review, 31, 1-54.

Produce Exchange Stock Clearing Association, Inc. v. Helvering, Commissioner of Internal Revenue, 71 F.2d 142 (2nd Cir. 1934).

Public Law 89-800, 15 U.S.C. § 1291 (1966).

Quirk, J., \& Fort, R. (1997). Pay dirt: The business of professional team sports. Princeton, NJ: Princeton University Press.

Reilly, J., \& Allen, B. (2003). Political campaign and lobbying activities of IRC 501(c)(4), (c)(5), and (c)(6) organizations. Exempt Organizations-Technical Instruction Program for FY 2003. Retrieved from http://www.irs.gov/pub/irs-tege/eotopic103.pdf.

Reilly, J., Hull, C., \& Allen, B. (2003). IRC 501(c)(6) organizations. Exempt Organizations-Technical Instruction Program for FY 2003. Retrieved from http://www.irs. gov/pub/irs-tege/eotopick03.pdf.

Retailers Credit Association of Alameda County v. Commissioner of Internal Revenue, 90 F.2d 47 (1937).

Roberts, D. (2015, April 29). NFL drops tax exempt status, gains good PR. Fortune. Retrieved from http://fortune.com/2015/04/29/nfl-tax-exempt-status/.

Rovell, D. (2014, July 10). NFL teams split \$6B in revenue. Retrieved from http://espn. go.com/nfl/story/_id/11200179/nfl-teams-divided-6-billion-revenue-according-greenbay-packers-financials.

Rovell, D. (2015, April 28). NFL league office relinquishing tax-exempt status. Retrieved from http://espn.go.com/nfl/story/_/id/12780874/nfl-league-office-gives-tax-exemptstatus.

Sandomir, R. (2010, January 26). Congress's team: Deal for merger included Saints. The New York Times. Retrieved from http://www.nytimes.com/2010/01/27/sports/football/ 27sandomir.html?_r=0.

Schmied, C. (2014). Official timeout on the field: Critics have thrown a red flag and are challenging the NFL's tax-exempt status, calling for it to be revoked. Jeffrey S. Moorad Sports Law Journal, 21, 577-612.

Schramm, T. (1966, June 20). Here's how it happened. Sports Illustrated. Retrieved from http://www.si.com/vault/1966/06/20/608557/heres-how-it-happened. 
Seifried, C., \& Pastore, D. (2009). Analyzing the first permanent professional baseball and football structures in the United States: How expansion and renovation changed them into jewel boxes. Sport History Review, 40, 167-196.

Smith, B. (2010). The tax-exempt status of the NCAA: Has the IRS fumbled the ball? Sports Lawyers Journal, 17, 117-134.

Spector, J. (2013, November 30). Don't strip away the NFL's tax exempt status. U.S. News and World Report. Retrieved from http://www.usnews.com/opinion/articles/2013/11/30/ 29twotakesspector.

Steinbach, D. (2013, July 23). Billion dollar baby: U.S. Chamber is first to hit lobbying milestone. Retrieved from http://www.opensecrets.org/news/2013/07/ billion-dollar-babyus-chamber-is-first-to-hit-lobbying-milestone/.

Tariff Act of 1913, § IIG (a), 38 Stat. (1915).

Tracy, M. (2014, September 16). Bill targets pro sports leagues' tax-exempt status. The New York Times. Retrieved from http://www.nytimes.com/2014/09/17/sports/football/ bill-targets-pro-sports-leagues-tax-exempt-status.html?_r=0.

Treasury Regulation 45, Article 518. (1919).

Treasury Regulation 69, Article 518. (1926).

Treasury Regulation 74, Article 528. (1929).

Treasury Regulation $\$ 1.501(\mathrm{c})(6)-1$. (1978).

Treasury Regulation $§ 1.513-1(\mathrm{c})(2)(\mathrm{i})$. (1983).

Uniform Printing \& Supply Co. v. Commissioner, 9 B.T.A. 251 (1929).

van den Berg, D. (2013, November 23). NFL's tax exemption faces scrutiny. Retrieved from http://www.taxanalysts.com/www/features.nsf/Articles/F0E1DC440C69E6A785257C 2E006AEE33?OpenDocument.

Weissmann, J. (2014, September 18). The NFL is not a nonprofit. Retrieved from http:// www. slate.com/articles/business/moneybox/2014/09/the_nfl_should_lose_its_tax_ exempt_status_the_league_is_not_a_nonprofit.html.

Williams, D., \& Seifried, C. (2013). The taxing postseason: The potential impact of unrelated business income taxation on college football bowl organizers. Journal of Legal Aspects of Sport, 23, 72-90.

Woolard, L. (2013, October 19). Revoke the tax-exempt status of the National Football League. Retrieved https://www.change.org/p/congress-revoke-the-tax-exempt-statusof-the-national-football-league. 